\title{
The effect of genetic variations in the choline acetyltransferase gene (ChAT) on waterpipe tobacco smoking dependence
}

\author{
Omar F. Khabour', Rawan N. Abu-Eitah' ${ }^{1}$ Karem H. Alzoubi', Ahmed Abu-Siniyeh ${ }^{3}$, Thomas Eissenberg ${ }^{4,5}$
}

\begin{abstract}
INTRODUCTION Waterpipe tobacco smoking (WS) is a popular form of tobacco use, globally. While the impact of genetic variations on smoking behavior has been well-investigated, few studies have examined this issue with regard to WS. In the current study, associations between choline acetyltransferase gene (ChAT) rs1917810 and rs7094248 polymorphisms and WS dependence were examined. METHODS Genotyping of rs1917810 and rs7094248 in 266 Jordanian waterpipe smokers was performed using RFLP-PCR. Dependence on WS was measured using the LWDS-10J scale.

RESULTS The frequency of rs $1917810 \mathrm{G}$ allele was $38.5 \%$ and that of the rs 7094248 $\mathrm{G}$ allele was $40.8 \%$. The rs 1917810 was significantly associated with the WS dependence level $(\mathrm{p}<0.05)$. Carriers of the AA genotype of rs1917810 were more dependent on WS than those with GG genotype $(\mathrm{p}<0.05)$. However, no association between rs7094248 single-nucleotide polymorphism (SNP) and dependence on WS was observed ( $\mathrm{p}>0.05)$.

concLusions The rs1917810 in the ChAT gene might be associated with dependence on WS.
\end{abstract}

\author{
AFFILIATION \\ 1 Department of Medical \\ Laboratory Sciences, Jordan \\ University of Science and \\ Technology, Irbid, Jordan \\ 2 Department of Clinical \\ Pharmacy, Jordan University \\ of Science and Technology, \\ Irbid, Jordan \\ 3 Department of Clinical \\ Laboratory Sciences, College \\ of Applied Medical Sciences, \\ Taif University, Taif, Kingdom \\ of Saudi Arabia \\ 4 Department of Psychology, \\ Virginia Commonwealth \\ University, Richmond, United \\ States \\ 5 Center for the Study of \\ Tobacco Products, Virginia \\ Commonwealth University, \\ Richmond, United States \\ CORRESPONDENCE TO \\ Karem H. Alzoubi. Department \\ of Clinical Pharmacy, Jordan \\ University of Science and \\ Technology, Irbid 22110, \\ Jordan. \\ E-mail: alzoubi@just.edu.jo \\ KEYWORDS \\ tobacco, waterpipe, choline \\ acetyltransferase gene, \\ dependence, SNP \\ Received: 30 November 2019 \\ Revised: 7 February 2020 \\ Accepted: 17 February 2020
}

\section{INTRODUCTION}

Tobacco smoking is a leading cause of preventable diseases and death worldwide ${ }^{1,2}$. More than 6 million people die from tobacco smoking each year, accounting for about $10 \%$ of all deaths ${ }^{3}$. Waterpipe tobacco smoking (WS) has become a global form of tobacco use $\mathrm{e}^{4,5}$, especially among adolescents and young adults ${ }^{6-8}$. For example, in Jordan, prevalence estimates of WS exceeded other tobacco use forms, including cigarettes ${ }^{9,10}$. In addition, according to a study conducted on university students in Middle East and North Africa (MENA) countries, Jordan ranked first in WS use ${ }^{11}$. The widespread of WS is due, in part, to its favorable smell and taste, the social settings 
in which it is used commonly, and the misconception that WS is less harmful than other tobacco use forms ${ }^{12}$.

When WS is compared to cigarette smoking, both forms share a similar profile of toxicants and carcinogens ${ }^{13,14}$. In addition, both forms increase blood nicotine, which upregulates nicotine receptors in the reward centers of the brain, setting up a potential for nicotine addiction ${ }^{15,16}$.

Describing any genetic influence on smoking behavior would improve understanding of the etiology of tobacco dependence and potentially influence tobacco cessation strategies ${ }^{17}$. Previous studies support the relation between the cholinergic system and tobacco/nicotine dependence ${ }^{18-21}$. Choline acetyltransferase is an enzyme encoded by the ChAT gene and is responsible for synthesis of acetyl choline $^{22}$. Several variations in the ChAT gene have been found to be related to smoking behavior ${ }^{19,23}$. Among such variations is the rs1917810 singlenucleotide polymorphism (SNP) that has been shown to be associated with smoking cessation ${ }^{19}$.

Findings of previous studies on cigarette smoking have identified different genetic variants associated with smoking behavior phenotypes, including initiation, dependence, and cessation ${ }^{24-27}$. Studies examining the influence of genetic variation on WS behavior are lacking. Therefore, in the current study, we aimed to study the effect of rs7094248 and rs1917810 ChAT SNPs on WS dependence in a sample of exclusive waterpipe smokers from Jordan.

\section{METHODS}

\section{Study participants}

The study design was cross-sectional and investigated genetic variations that contribute to waterpipe smoking behavior. Participants were Arab Jordanian adults who were 'current' waterpipe smokers and who reported that they smoked tobacco in a waterpipe exclusively (i.e. no cigarette or any other smoking types, including e-cigarettes). Participants were recruited from universities, cafes and restaurants from Central and Northern regions of Jordan. Exclusion criteria were any tobacco use other than WS. A total of 266 males and females, who qualified, participated by completing a questionnaire and donating a blood sample. The Institutional Review Board (IRB) at Jordan University of Science and Technology approved the study (Approval Number: 195/2012). Written informed consent was collected from all participants, as required by the IRB.

\section{Waterpipe data collection}

A previously validated questionnaire was used to collect sociodemographic characteristics and waterpipe tobacco use among participants ${ }^{28-30}$. The questionnaire included the 10 items of the Lebanese Waterpipe Dependence Scale that has been validated in Jordan $(\text { LWDS-10J })^{26}$ and used to estimate and measure WS dependence level. Based on a threshold score of 10, smokers were categorized ${ }^{30}$ into: mild smokers with LWDS-10J score $\leq 10$; moderate smokers with LWDS10 J score $>10$ through $\leq 20$; and heavy smokers with LWDS-10J score $>20$. The questionnaire also asked about 'quit attempt', which is defined in the current study as stopping the use of waterpipe for a period with an intention to quit smoking.

\section{Blood samples and DNA extraction}

About $3 \mathrm{~mL}$ of venous blood were collected from each participant in EDTA vacutainer tubes. DNA was extracted from blood samples using Wizard Genomic DNA Purification Kit (Promega) according to the standard manufacturer instructions. Concentration and quality of extracted DNA were checked and then samples were stored at $-20{ }^{\circ} \mathrm{C}$ until used ${ }^{31}$.

\section{Genotyping of rs1917810 and rs7094248 SNPs in ChAT gene}

Genotyping of rs1917810 and rs7094248 SNPs in ChAT gene was performed by using standard PCR, followed by restriction fragment length polymorphism (PCR-RFLP) technique. Target DNA was amplified using the forward primer 5'TGAGCGTGCTAAGGGGTCTA -3 ' and the reverse 5'- GAGCCCAGGGAACAAGAGAT -3' for rs1917810, and forward primer 5'- TTGCTCACCAAGCAAGACAG -3' and reverse 5'- GTCCTTGATGTTGGGAGTGG -3' for rs7094248. The PCR conditions were as previously described $^{19}$. The $152 \mathrm{bp}$ amplification product was digested at $37{ }^{\circ} \mathrm{C}$ overnight by $\mathrm{XmnI}$ restriction enzyme (New England Biolabs, Frankfurt, Germany). On the other hand, the $159 \mathrm{bp}$ amplification product for rs 1917810 was digested at $37^{\circ} \mathrm{C}$ overnight by TfiI restriction enzyme (New England Biolabs, Frankfurt, Germany). 


\section{Statistical analysis}

SPSS version 22.0 (Inc., Chicago, IL) was used for data analysis using the statistical package for the social sciences. Chi-squared test was used for: 1) comparing genotype and allele frequencies, and 2) testing whether individual variants were in Hardy-Weinberg equilibrium (HWE) at each locus in the samples. One-way ANOVA, followed by Tukey's post hoc test, was used to compare addiction scores according to genotype. A $p<0.025$ was used to indicate significant difference between groups.

\section{RESULTS}

Sociodemographic characteristics of the 266 participants (Table 1) showed that $53.6 \%$ of the participants were men, and mean age was 29.2 years ( $\mathrm{SD}=9.8$, range 18-62 years). About half of the sample (45.8\%) reported a household income between 5011100 JOD (1 JOD about 1.41 US\$), which reflects the average household income in Jordan (approximately 550 JOD, Jordanian Dinar).

About $40.5 \%$ of the participants started WS during school age (Table 2). Among participants, 47.2\% reported daily WS, while weekly was reported by $37.1 \%$, and monthly by $15.4 \%$. Regarding duration of WS session, $37.1 \%$ of participants spend less than 60 minutes per session, and about one-third (32.6\%) spend between 1-2 hours. The majority (53.9\%) smoked one head per session. About $74.8 \%$ owned a waterpipe and $62.5 \%$ took it to places that did not

Table 1. Participant sociodemographic characteristics, Jordan $(\mathrm{N}=266)$

\begin{tabular}{l|r}
\hline Tariables & $\begin{array}{r}\text { IVaterpipe smokers } \\
\text { n (\%o }\end{array}$ \\
\hline Age (years), mean \pm SD & $29.2 \pm 9.8$ \\
$18-29$ & $159(59.8)$ \\
$30-39$ & $64(24.1)$ \\
$\geq 40$ & $43(16.2)$ \\
Gender & \\
Male & $143(53.6)$ \\
Female & $121(45.3)$ \\
Monthly household income (JOD) & \\
$<500$ & $35(13.1)$ \\
$501-1100$ & $122(45.8)$ \\
$>1100$ & $109(40.8)$
\end{tabular}

JOD: 1 Jordanian Dinar about 1.41 US\$. offer waterpipe. No more than $44.4 \%$ of participants reported a WS quit attempt (Table 2).

Table 3 shows the genotypes and allele frequencies of rs1917810 and rs7094248 SNPs and level of addiction based on LWDS-10J dependence categories (heavy, moderate, mild). The rs1917810 SNP genotypes are associated with waterpipe dependence $(\mathrm{p}<0.05)$. The frequency of AA genotype of the rs1917810 SNP was higher in heavy smokers, whereas the GG genotype frequency was higher in mild smokers. When allele frequencies were considered, the A allele was related mainly to heavy smokers and $\mathrm{G}$ allele to mild smokers $(\mathrm{p}<0.01)$. With respect to rs7094248 SNP, no significant association was found with waterpipe dependence ( $\mathrm{p}>0.05$ ) (Table 3 ).

The association between quit attempts of WS and rs1917810 and rs7094248 SNPs is shown in Table 4. A significant association between quit attempts and

\section{Table 2. Waterpipe smoking characteristics of participants, Jordan $(\mathrm{N}=266)$}

\begin{tabular}{|c|c|}
\hline Variables & $\begin{array}{l}\text { Waterpipe smokers } \\
\text { n ( (\%) }\end{array}$ \\
\hline \multicolumn{2}{|l|}{$\begin{array}{l}\text { Age of initiation waterpipe smoking } \\
\text { (years) }\end{array}$} \\
\hline$\leq 14$ (middle school range) & $32(12.0)$ \\
\hline 15-17 (high school range) & $76(28.5)$ \\
\hline 18-21 (university range) & $82(30.8)$ \\
\hline$>21$ & $76(28.5)$ \\
\hline $\begin{array}{l}\text { Duration of smoking since initiation } \\
\text { (years), mean } \pm S D\end{array}$ & $9.57 \pm 3.8$ \\
\hline \multicolumn{2}{|l|}{ Frequency of smoking } \\
\hline Daily & $126(47.2)$ \\
\hline Weekly & $99(37.1)$ \\
\hline Monthly & $41(15.4)$ \\
\hline \multicolumn{2}{|l|}{ Waterpipe session duration (hours) } \\
\hline$<1$ & $99(37.1)$ \\
\hline $1-2$ & $87(32.6)$ \\
\hline$>2$ & $80(30)$ \\
\hline \multicolumn{2}{|l|}{$\begin{array}{l}\text { Number of tobacco heads per } \\
\text { session }\end{array}$} \\
\hline 1 & $144(53.9)$ \\
\hline 2 & $71(26.6)$ \\
\hline$\geq 3$ & $51(19.2)$ \\
\hline Owned waterpipe device & $199(74.8)$ \\
\hline $\begin{array}{l}\text { Took waterpipe to places that did } \\
\text { not provide it (if owned) }\end{array}$ & $167(62.5)$ \\
\hline Made quit attempts & $118(44.4)$ \\
\hline
\end{tabular}


Table 3. Genotype and allele frequencies of rs1917810 and rs7094248 by waterpipe smoking dependence level, among adults, Jordan ( $\mathrm{N}=266)$

\begin{tabular}{|c|c|c|c|c|}
\hline \multicolumn{5}{|c|}{ rs1917810 } \\
\hline & \multicolumn{3}{|c|}{ Dependence level (N 266), 1 (\%) } & \multirow{2}{*}{$\begin{array}{l}\text { Chi- } \\
\text { squared } \\
\text { statistics }\end{array}$} \\
\hline Genotype & $\begin{array}{l}\text { Ileavy } \\
\text { (23) }\end{array}$ & $\begin{array}{c}\text { Moderate } \\
\text { (83) }\end{array}$ & $\begin{array}{l}\text { Vild } \\
(160)\end{array}$ & \\
\hline $\mathrm{A} / \mathrm{A}$ & $14(14.3)$ & $35(35.7)$ & $49(50.0)$ & \multirow{3}{*}{$\begin{array}{l}X^{2}(2, \\
N=266)= \\
12.89 \\
p=0.0118\end{array}$} \\
\hline$A / G$ & $7(5.3)$ & $42(32.1)$ & $82(62.6)$ & \\
\hline $\mathrm{G} / \mathrm{G}$ & $2(5.4)$ & $6(16.2)$ & $29(78.4)$ & \\
\hline Allele A & $35(10.7)$ & $112(34.3)$ & $180(55.0)$ & \multirow{2}{*}{$\begin{array}{l}X^{2}(2, \\
N=532)= \\
10.35 \\
p=0.0056\end{array}$} \\
\hline Allele $\mathbf{G}$ & $11(5.4)$ & $54(26.3)$ & $140(68.3)$ & \\
\hline \multicolumn{5}{|c|}{ Is 7091218} \\
\hline & \multicolumn{3}{|c|}{ Dependence level (N 266), n (\%) } & \multirow{2}{*}{$\begin{array}{l}\text { Chi- } \\
\text { squared } \\
\text { statistics }\end{array}$} \\
\hline Genotype & $\begin{array}{c}\text { Ileavy } \\
\text { (23) }\end{array}$ & $\begin{array}{c}\text { Moderate } \\
\text { (83) }\end{array}$ & $\begin{array}{l}\text { Villd } \\
(160)\end{array}$ & \\
\hline $\mathrm{c} / \mathrm{C}$ & $8(8.04)$ & 27 (29.02) & $58(55.94)$ & \multirow{3}{*}{$\begin{array}{l}X^{2}(2, \\
N=266)= \\
5.17 \\
p=0.269\end{array}$} \\
\hline $\mathrm{C} / \mathrm{G}$ & $9(11.15)$ & $47(40.25)$ & $73(77.59)$ & \\
\hline $\mathrm{G} / \mathrm{G}$ & $6(3.80)$ & $9(13.73)$ & $29(26.47)$ & \\
\hline Allele C & $25(27.24)$ & 101 (98.29) & $189(189.47)$ & \multirow{2}{*}{$\begin{array}{l}X^{2}(2 \\
N=532)= \\
0.636 \\
p=0.727\end{array}$} \\
\hline Allele $\mathbf{G}$ & $21(18.76)$ & $65(67.71)$ & $131(130.53)$ & \\
\hline
\end{tabular}

rs1917810 genotypes was detected $(\mathrm{p}<0.05)$. The frequency of AA was lower in individuals who made quit attempts than those who did not $(34.7 \%$ versus $65.3 \%$, respectively). In addition, when alleles were considered, the A allele was found to be associated with fewer quit attempts $(\mathrm{p}<0.05)$. With respect to rs7094248 SNP, no significant association was found with quit attempts $(\mathrm{p}>0.05)$ (Table 4$)$.

\section{DISCUSSION}

This study examined the association of rs 1917810 and rs7094248 SNPs in the ChAT gene with WS dependence, in a sample of exclusive waterpipe smokers. The results showed an association between rs1917810 SNP and WS dependence and quitting. Results of previous studies on cigarette smoking have identified different genetic variants among genes incorporated with several neuronal pathways associated with smoking behavior phenotypes,
Table 4. Genotype of rs1917810 and rs7094248 among waterpipe smokers with respect to quit attempts among adults, Jordan $(\mathrm{N}=266)$

\begin{tabular}{|c|c|c|c|c|}
\hline \multirow[t]{2}{*}{ SNP } & & \multicolumn{2}{|c|}{ Vade quit attempts } & \multirow[b]{2}{*}{$\begin{array}{l}\text { Chi- } \\
\text { squared } \\
\text { statistices }\end{array}$} \\
\hline & & Yes & No & \\
\hline \multirow[t]{3}{*}{$\begin{array}{l}\text { rs1917810 } \\
\text { Genotype }\end{array}$} & $A / A$ & $34(34.7)$ & $64(65.3)$ & $\begin{array}{l}X^{2}(2, \\
N=266)= \\
5.98 \\
p=0.050\end{array}$ \\
\hline & $A / G$ & $66(50.4)$ & 65 (49.6) & \\
\hline & $\mathrm{G} / \mathrm{G}$ & 18 (48.7) & $19(51.3)$ & \\
\hline \multirow[t]{2}{*}{$\begin{array}{l}\text { rs1917810 } \\
\text { alleles }\end{array}$} & Allele A & $134(41)$ & 193 (59) & $\begin{array}{l}X^{2}(1 \\
N=532)= \\
3.93 \\
p=0.047\end{array}$ \\
\hline & Allele G & $102(49.8)$ & $103(50.2)$ & \\
\hline \multirow[t]{3}{*}{$\begin{array}{l}\text { rs7094248 } \\
\text { Genotypes }\end{array}$} & $\mathrm{c} / \mathrm{C}$ & 40 (43.0) & $53(57.0)$ & $\begin{array}{l}X^{2}(2, \\
N=266)= \\
0.523 \\
p=0.769\end{array}$ \\
\hline & $C / G$ & 60 (46.5) & 69 (53.5) & \\
\hline & $\mathrm{G} / \mathrm{G}$ & $18(40.9)$ & $26(59.1)$ & \\
\hline \multirow[t]{2}{*}{$\begin{array}{l}\text { rs7094248 } \\
\text { alleles }\end{array}$} & Allele C & $140(44.4)$ & $175(55.6)$ & $\begin{array}{l}X^{2}(1 \\
N=532)= \\
0.002 \\
p=0.963\end{array}$ \\
\hline & Allele G & $96(44.2)$ & $121(55.8)$ & \\
\hline
\end{tabular}

including initiation, dependence, and cessation ${ }^{24-27}$. Nicotine is associated with tobacco dependence by affecting the release of different neurotransmitters including acetylcholine and dopamine in the central reward pathway of the brain ${ }^{23,25}$. Choline acetyltransferase enzyme is an important player in cholinergic neurons ${ }^{32}$ and nicotine modulates its expression and activity ${ }^{23}$. The ChAT gene was suggested as a biologically plausible candidate to be associated with smoking dependence and smoking behavior.

The results of the current study showed a statistically significant association between the rs1917810 SNP and WS dependence, as measured using LWDS-10J. In addition, the rs1917810 SNP was associated with quitting. This is consistent with the study of Ray et al. ${ }^{19}$ that reported evidence of a convergent association between ChAT rs1917810 SNP and both smoking cessation and nicotine 
dependence. The present findings suggest that a significant genotypic difference exists at the three levels of addiction: heavy, moderate, and mild. The minor allele $G$ being expressed more highly than the $A$ allele in mild smokers, presenting a lower addiction level than that found with $\mathrm{A}$ allele. This result supports the notion that genetic variation in the ChAT gene contributes to the level of WS dependence and quitting. However, a previous study ${ }^{23}$ reported no significant association between nicotine dependence and rs1917810 SNP. With respect to rs7094248, the results showed a lack of association between this SNP and WS dependence. This is consistent with a previous study that reported that rs 7094248 was not associated with smoking dependence among treatment-seeking smokers of European ancestry ${ }^{19}$.

\section{Limitations}

Among the limitations of the current study is the relatively small sample size, a result of our attempt to include individuals who smoked tobacco with a waterpipe only. Additional studies with larger sample sizes are needed, though the same challenge remains, and these studies might also require additional ChAT SNPs. Pharmacogenetic studies are also recommended to examine the impact of rs1917810 SNP on WS treatment. Moreover, determining the generalizability of the results reported here may require replication using participants across various world regions. Finally, covariates related to smoking habits or dependence, such as education, socioeconomic level and exposure to secondhand smoke etc., might affect the observed genetic association with waterpipe smoking behavior. Thus, it is recommended that such confounders are considered in future studies.

\section{CONCLUSIONS}

Individual SNP association analysis revealed that ChAT is associated with WS behavior that includes dependence and quit attempts, making ChAT a suitable target for additional research on the mechanisms underlying association with WS dependence.

\section{REFERENCES}

1. Islami F, Stoklosa M, Drope J, Jemal A. Global and Regional Patterns of Tobacco Smoking and Tobacco Control Policies. Eur Urol Focus. 2015;1(1):3-16. doi:10.1016/j.euf.2014.10.001

2. West R. Tobacco smoking: Health impact, prevalence, correlates and interventions. Psychol Health. 2017;32(8):1018-1036. doi:10.1080/08870446.2017.1325890

3. Perez-Warnisher MT, de Miguel MDPC, Seijo LM. Tobacco Use Worldwide: Legislative Efforts to Curb Consumption. Ann Glob Health. 2019;85(1). doi:10.5334/aogh.2417

4. Jawad M, Charide R, Waziry R, Darzi A, Ballout RA, Akl EA. The prevalence and trends of waterpipe tobacco smoking: A systematic review. PLoS One. 2018;13(2):e0192191. doi:10.1371/journal.pone.0192191

5. Lopez AA, Eissenberg T, Jaafar M, Afifi R. Now is the time to advocate for interventions designed specifically to prevent and control waterpipe tobacco smoking. Addict Behav. 2017;66:41-47. doi:10.1016/j.addbeh.2016.11.008

6. Alomari MA, Al-Sheyab NA, Khabour OF, Alzoubi KH. Brain-derived neutrophic factor in adolescents smoking waterpipe: The Irbid TRY. Int J Dev Neurosci. 2018;67:14-18. doi:10.1016/j.ijdevneu.2018.03.007

7. Azagba S, Latham K, Shan L. Waterpipe tobacco smoking trends among middle and high school students in the United States from 2011 to 2017. Drug Alcohol Depend. 2019;200:19-25. doi:10.1016/j.drugalcdep.2019.04.005

8. Ramji R, Nilsson M, Arnetz B, Wiklund Y, Arnetz J. Taking a Stand: An Untapped Strategy to Reduce Waterpipe Smoking in Adolescents. Subst Use Misuse. 2019;54(3):514-524. doi:10.1080/10826084.2018.1521429

9. Al-Sheyab N, Alomari MA, Shah S, Gallagher P, Gallagher R. Prevalence, patterns and correlates of cigarette smoking in male adolescents in northern Jordan, and the influence of waterpipe use and asthma diagnosis: a descriptive cross-sectional study. Int J Environ Res Public Health. 2014;11(9):9008-9023. doi:10.3390/ijerph110909008

10. Bibars AR, Obeidat SR, Khader Y, Mahasneh AM, Khabour OF. The Effect of Waterpipe Smoking on Periodontal Health. Oral Health Prev Dent. 2015;13(3):253-259. doi:10.3290/j.ohpd.a32671

11. Salloum RG, Lee J, Mostafa A, et al. Waterpipe Tobacco Smoking among University Students in Three Eastern Mediterranean Countries: Patterns, Place, and Price. Subst Use Misuse. 2019:54(14):2275-2283. doi:10.1080/10826084.2019.1645177

12. Maziak W, Jawad M, Jawad S, Ward KD, Eissenberg $\mathrm{T}$, Asfar T. Interventions for waterpipe smoking cessation. Cochrane Database Syst Rev. 2015;(7). doi:10.1002/14651858.CD005549.pub3

13. Jawad M, Eissenberg T, Salman R, et al. Toxicant inhalation among singleton waterpipe tobacco users in natural settings. Tob Control. 2019;28(2):181-188. doi:10.1136/tobaccocontrol-2017-054230

14. Primack BA, Carroll MV, Weiss PM, et al. Systematic Review and Meta-Analysis of Inhaled Toxicants from Waterpipe and Cigarette Smoking. Public Health Rep. 2016;131(1):76-85. doi:10.1177/003335491613100114 
15. Bahelah R, Ward KD, Ben Taleb Z, et al. Determinants of progression of nicotine dependence symptoms in adolescent waterpipe smokers. Tob Control. 2019;28(3):254-260. doi:10.1136/tobaccocontrol-2018-054244

16. Eissenberg T, Shihadeh A. Waterpipe tobacco and cigarette smoking: direct comparison of toxicant exposure. Am J Prev Med. 2009;37(6):518-523. doi:10.1016/j.amepre.2009.07.014

17. Hancock DB, Guo Y, Reginsson GW, et al. Genome-wide association study across European and African American ancestries identifies a SNP in DNMT3B contributing to nicotine dependence. Mol Psychiatry. 2018;23(9):19111919. doi:10.1038/mp.2017.193

18. Gozen O, Nesil T, Kanit L, Koylu EO, Pogun S. Nicotinic cholinergic and dopaminergic receptor mRNA expression in male and female rats with high or low preference for nicotine. Am J Drug Alcohol Abuse. 2016;42(5):556-566. doi:10.1080/00952990.2016.1198799

19. Ray R, Mitra N, Baldwin D, et al. Convergent evidence that choline acetyltransferase gene variation is associated with prospective smoking cessation and nicotine dependence. Neuropsychopharmacology. 2010;35(6):1374-1382. doi:10.1038/npp.2010.7

20. Scherma M, Muntoni AL, Melis M, et al. Interactions between the endocannabinoid and nicotinic cholinergic systems: preclinical evidence and therapeutic perspectives. Psychopharmacology. 2016;233(10):17651777. doi:10.1007/s00213-015-4196-3

21. Wilar G, Anggadiredja K, Shinoda Y, Fukunaga K. Inhibition of Nicotine Dependence by Curcuminoid Is Associated with Reduced Acetylcholinesterase Activity in the Mouse Brain. Pharmacology. 2018;102(3-4):223-232. doi:10.1159/000492154

22. Bellier JP, Kimura H. Peripheral type of choline acetyltransferase: biological and evolutionary implications for novel mechanisms in cholinergic system. J Chem Neuroanat. 2011;42(4):225-235. doi:10.1016/j.jchemneu.2011.02.005

23. Wei J, Ma JZ, Payne TJ, et al. Replication and extension of association of choline acetyltransferase with nicotine dependence in European and African American smokers. Hum Genet. 2010;127(6):691-698. doi:10.1007/s00439-010-0818-3

24. Cameli C, Bacchelli E, De Paola M, et al. Genetic variation in CHRNA7 and CHRFAM7A is associated with nicotine dependence and response to varenicline treatment. Eur J Hum Genet. 2018;26(12):1824-1831. doi:10.1038/s41431-018-0223-2

25. Gold AB, Lerman C. Pharmacogenetics of smoking cessation: role of nicotine target and metabolism genes. Hum Genet. 2012. doi:10.1007/s00439-012-1143-9

26. Gu F, Zhao C, Jiang T, Li X, Mao Y, Zhou C. Association Between Nicotine-dependent Gene Polymorphism and Smoking Cessation in Patients With Lung Cancer. Clin Lung Cancer. 2019. doi:10.1016/j.cllc.2019.07.002

27. Ohmoto M, Takahashi T. Effect of genetic polymorphism of brain-derived neurotrophic factor and serotonin transporter on smoking phenotypes: A pilot study of Japanese participants. Heliyon. 2019;5(2):e01234. doi:10.1016/j.heliyon.2019.e01234

28. Alzoubi KH, Khabour OF, Azab M, et al. CO exposure and puff topography are associated with Lebanese waterpipe dependence scale score. Nicotine Tob Res. 2013;15(10):1782-1786. doi:10.1093/ntr/ntt049

29. Azab M, Khabour OF, Alzoubi KH, Mahmoud SA, Anabtawi M, Quttina M. Assessment of genotoxicity of waterpipe smoking using 8-OHdG biomarker. Genet Mol Res. 2015;14(3):9555-9561. doi:10.4238/2015.August.14.18

30. Primack BA, Khabour OF, Alzoubi KH, et al. The LWDS-10J: reliability and validity of the Lebanon Waterpipe Dependence Scale among university students in Jordan. Nicotine Tob Res. 2014;16(7):915-922. doi:10.1093/ntr/ntu002

31. Khabour OF, Abu-Rumeh L, Al-Jarrah M, Jamous M, Alhashimi F. Association of adiponectin protein and ADIPOQ gene variants with lumbar disc degeneration. Exp Ther Med. 2014;8(4):1340-1344. doi:10.3892/etm.2014.1909

32. Ronowska A, Szutowicz A, Bielarczyk H, et al. The Regulatory Effects of Acetyl-CoA Distribution in the Healthy and Diseased Brain. Front Cell Neurosci. 2018;12(169). doi:10.3389/fncel.2018.00169

\section{CONFLICTS OF INTEREST}

The authors have each completed and submitted an ICMJE form for disclosure of potential conflicts of interest. The authors declare that they have no competing interests, financial or otherwise, related to the current work. T. Eissenberg reports grants from US FDA/NIH during the conduct of the study and personal fees from legal firms, outside the submitted work. In addition, T. Eissenberg has a patent issued for a device that measures the puffing behavior of electronic cigarette users.

\section{FUNDING}

This study (Project Number 195/2012) was funded by the Deanship of Research, Jordan University of Science and Technology, Irbid, Jordan. T. Eissenberg was supported during this study by the National Institute on Drug Abuse of the U.S. National Institutes of Health (NIH) and the Center for Tobacco Products of the U.S. Food and Drug Administration (FDA) under Award Number U54DA036105. The content of this work is solely the responsibility of the authors and does not necessarily represent the official views of the NIH or FDA.

\section{AUTHORS' CONTRIBUTIONS}

OFK participated in study design, genetic analysis of samples, data analysis and interpretation. RNAE participated in study design, samples collection, and genetic analysis of samples, data analysis and interpretation. KHA participated in study design, subject recruitment, statistical analysis and interpretation. AAS participated in study design, analysis of blood samples, data analysis and interpretation. TE participated in study design, data analysis, and results interpretation. All authors participated in manuscript drafting and revisions.

\section{PROVENANCE AND PEER REVIEW}

Not commissioned; externally peer reviewed. 